\title{
ZFP42 wt Allele
}

National Cancer Institute

\section{Source}

National Cancer Institute. ZFP42 wt Allele. NCI Thesaurus. Code C94683.

Human ZFP42 wild-type allele is located in the vicinity of $4 \mathrm{q} 35.2$ and is approximately $9 \mathrm{~kb}$ in length. This allele, which encodes zinc finger protein 42 homolog, may play a role in the regulation of both transcription and embryonic stem cell development. 